\title{
Light microscopic determination of tissue
}

\author{
Fadime Kahyaoğlu ${ }^{1 *}$ and Alpaslan Gökçimen ${ }^{2}$ \\ ${ }^{1}$ Vocational School of Health Services, Pathology Laboratory Techniques, University of Avrasya, Trabzon, Turkey \\ ${ }^{2}$ Department of Histology and Embryology, University of Adnan Menderes, Faculty of Medicine, Aydin, Turkey
}

\begin{abstract}
Tissues to be examined under a light microscope, must pass through certain stages. These are; detection(fixation), washing, dewatering (dehydration), polishing or transparent, absorption, recession or blocking, cutting, coloring and closing the lamella. At the end of this phase examination of the tissues with a light microscope takes place. Mistakes at any stage, may lead to irreparable consequences. For this purpose, the researcher during the examination of biological materials should properly fulfill tissue tracking methods. It is aimed to review the existing information about the first phase of tissue detection and to review and compile new publications. It was aimed to review present knowledge and recent literature on the fixation step which is the first step in tissue determination.
\end{abstract}

Key Words: Fixation, light microscope, formaldehyde, tissue detection

\section{Introduction}

For tissue or intracellular bacteria to prevent degradation by enzymes and to maintain their physiological structure, in the shortest possible time, quickly detection process is known as maintaining fidelity. In other words, in-vivo micro-anatomic imaging is achieved by tapping(1). In order to operate, chemical or physical methods are carried out but are less preferred (2).

Chemical methods include chemical cross-linking agents. They are formaldehyde and glutaraldehyde $(3,4)$. Isotonic buffered $4 \%$ formaldehyde solution is one of the best fasteners used in conventional light microscopy. On the other hand in electron microscope widely used primary fixing agent is glutaraldehyde, in which tissue protein amine groups $\left(\mathrm{NH}_{2}\right)$ are reacted. Glutaraldehyde, via a dialdehyde crosslinking strongly determines the tissue (2).

While formaldehyde penetrates tissue quickly, it detects proteins slowly. Physical fixation is done by freezing, coagulating, or precipitating components with the aid of heat, organic materials and acid. Examples of fixative solutions used with physical fixation methods include Clark $(75 \mathrm{ml}$ of ethanol and $25 \mathrm{ml}$ of acetic acid) and Carnoy (60 $\mathrm{ml}$ of ethanol, $30 \mathrm{ml}$ of chloroform and $10 \mathrm{ml}$ of acetic acid)(5).

In histology and pathology labs, formaldehyde is the most widely used detection solution (6). Formaldehyde gas becomes liquid at room temperature. Although it is a colorless gas it has an irritating smell $(7,8)$. It leads to dermatitis and can cause irritation to the eyes. At the same time due to its carcinogenic properties it also poses a serious threat to environment (6).

Despite the many advantages of formaldehyde in detecting tissues, in some cases this is unsuccessful. Antibody specifically used in immuno-peroxidase staining method; needs to be studied in fresh tissue, which gives no result in formaldehyde fixed tissues. This is because the antigenic epitope by the formaldehyde solution is modified or destroyed (9).

Formaldehyde cross-links molecular groups to prevent immunohistochemical reactions(6). These epitopes can be recovered with "epitope access method"(10). This is one of the methods of antigen retrieval (1). Antigen retrieval applications include enzymes, protein denaturation and temperature. It has been reported that heat is applied to formaldehyde fixation fractions in various solutions, resulting in cross-linking and increased immunostaining properties of many antigens in formalin-fixed and paraffin-embedded tissue sections(5) (Figure 1).

Formaldehyde is the most preferred fixation solution because it changes the antigenic structure of many proteins, resulting in a good structure (11).

Aktan et al. (12) in their study investigated the effects of Carnoy and 10\% formaldehyde solution in morphological and immunohistochemical staining of skin tissue. The obtained skin tissue samples were fixed in Carnoy and 10\% 

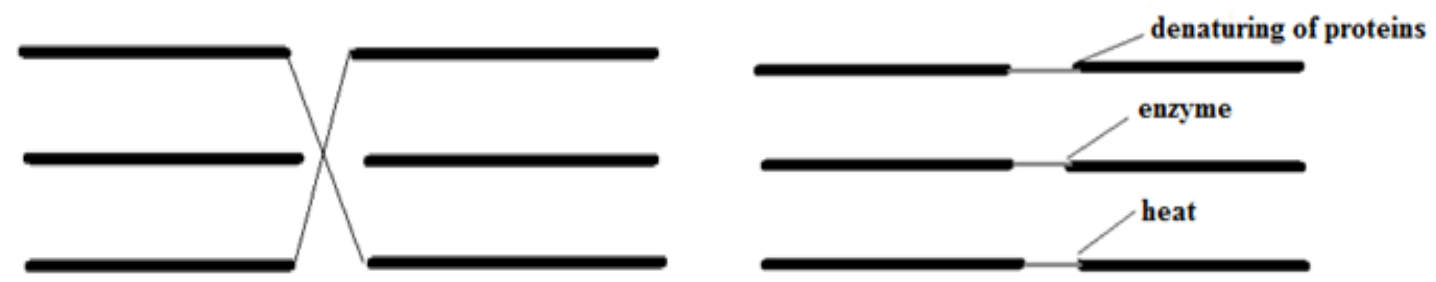

Fig. 1. Epitopes in several "epitope retrieval method" and recycling. Such epitopes can be recovered with "epitope access method". This is one of the methods of antigen retrieval. Antigen retrieval applications include enzymes, protein denaturation and temperature.

formaldehyde solution, and after the second day, the skin texture data were obtained with the same routine histological procedures. 5-micron-thick paraffin sections were stained by using hematoxylin-eosin, Masson trichrome and immunohistochemical dyes, F8, Ki67 and antiactin. Hematoxylin-eosin and Masson trichrome Carnoy and 10\% formaldehyde detection in tissue sections provides observation of morphological differences. However, in sections prepared from $10 \%$ formaldehyde-detected tissues, loss of tissue and deterioration in cross-sections of antigen, recovered by microwave, was observed. Especially more layer wear has been observed in the reticular dermis. It can be concluded that the sections of skin tissue prepared by Carnoy are more successful than the 10\% formaldehyde solution. Tissue sections detected in Carnoy solution gives more successful results than tissue sections detected in formaldehyde solution. It is less toxic than formaldehyde solution; It can be suggested as a powerful alternative (11).

Stability of proteins in tissue detection is the most important step in the process. It is known that fixatives show cross-linking between proteins, bringing them to gel form and protecting everything in a live state. In this regard, it is reported that soluble proteins become insolubly fixed to structural proteins. While there is not much information available on the effect of fixation on lipids, frozen sections are used because conventional fixation and tissue processing lead to the loss of lipids(13).

\section{Factors affecting fixation}

These factors are; hydrogen ion concentration $(\mathrm{pH})$, temperature, penetration, osmolality, concentration and time.

Hydrogen ion concentration $(\mathrm{pH})$ : $\mathrm{PH}$ changes in different fixation methods. In general, the hydrogen ion concentration will generally be in the physiological range by using a suitable buffer for $\mathrm{pH}$ adjustment. Best fixing for $\mathrm{pH}$ is between 6 and 8 . In the course of cell death, the $\mathrm{pH}$ in the cell decreases due to the anoxia. A specific $\mathrm{pH}$ range is selected in different studies. For example, the best $\mathrm{pH}$ range for gastric mucosa is 5.5. Similarly, in the case of the catecholamine chromophore reaction, storage granules for adrenaline and noradrenalin have been shown to be most stable in the presence of formalin at a $\mathrm{pH}$ of 6.5.(13).

Temperature: Routinely, the detection of tissue for light microscopy is performed at room temperature. For electron microscopy, and some histochemical studies temperature range is set between $0-4^{\circ} \mathrm{C}$. However, fixation is performed at room temperature for some cells, such as mast cells, for electron microscopy. Hopwood showed that fixatives which are used for the fixation of nucleic acids don't react in any temperature scale (14).

For bacteriology and for tissues such as blood samples which have an increased risk of deterioration, use of heat is chosen. It is known that formalin heated at $60^{\circ} \mathrm{C}$ is sometimes used for rapid detection of very urgent biopsy specimens. Formaldehyde at $100^{\circ} \mathrm{C}$ can be used for the detection of tuberculosis (13).

Penetration: It is an important event for texture. Since this process is quite slow, a block taken should be small (ex $1 \mathrm{~mm}$ electron microscopy) or fine to obtain adequate fixation. In this context, it should be guaranteed that the obtained samples should be thin enough for suitable fixing of the samples(13).

The researcher, Medawar, studied the diffusion rates of fixative in tissues. According to his formula; The depth of penetration is constantly proportional to the time square which is formulated as: $\mathrm{d}=\mathrm{K} \vee \mathrm{t}(15)$ (Table 1).

Osmolality: Cells shrink in hypertonic solutions. To correct this situation, hypotonic fixative process is applied. Criterion was obtained using light hypertonic solutions (400-450 mOsm, isotonic solutions with $340 \mathrm{mOsm}$ ). By changing the osmolality, it is possible to change the

East J Med Volume:22, Number:3, July-September/2017 
Table 1. Concentrations of specific tissues and the fixative gel diffusion rates

\begin{tabular}{lccc}
\hline Fixative & Fixative concentration $(\%)$ & $\mathrm{K}$ (tissue) & $\mathrm{K}(\mathrm{gel})$ \\
\hline Acetic acid & 5 & 1.2 & 2.75 \\
Chromium trioxide & 0.5 & 0.25 & 1 \\
Formaldehyde & 4 & 0.78 & 3.6 \\
Ethanol & 100 & 1 & -- \\
Glutaraldehyde & 6 & 1 & -- \\
Osmium tetroxide & $0.5-2$ & $0.29-0.58$ & 0.85 \\
\hline
\end{tabular}

Table 2. Commonly used fixative solutions (16):

\begin{tabular}{|c|c|c|}
\hline $\begin{array}{l}\text { Commonly } \\
\text { used fixative } \\
\text { solutions }\end{array}$ & Formulation & Recommended Applications \\
\hline $\begin{array}{l}\text { Phosphate } \\
\text { buffered } \\
\text { formalin }\end{array}$ & $\begin{array}{l}100 \mathrm{ml} 40 \% \text { formaldehyde } \\
900 \mathrm{ml} \text { Distilled water } \\
4 \mathrm{~g} \text { Sodium dihydrogen } \\
\text { phosphatemonohydrate } \\
6.5 \mathrm{~g} \text { Disodium hydrogen } \\
\text { phosphate anhydrous } \\
\text { The solution should have a } \\
\text { pH of } 6.8 \\
\text { Fixation time: } 12-24 \text { hours }\end{array}$ & $\begin{array}{l}\text { For routine histopathology this is the most widely used } \\
\text { formaldehyde based fixative. Phosphate buffer is chosen to } \\
\text { avoid formation of formalin pigment. Following its } \\
\text { administration many epitopes require antigen uptake for } \\
\text { successful IHC. }\end{array}$ \\
\hline Formal calcium & $\begin{array}{l}100 \mathrm{ml} 40 \% \text { formaldehyde } \\
10 \mathrm{~g} \text { Calcium chloride } \\
900 \mathrm{ml} \text { Distilled water } \\
\text { Fixation time: } 12-24 \text { hours }\end{array}$ & $\begin{array}{l}\text { Recommended for the preservation of lipids especially } \\
\text { phospholipids. }\end{array}$ \\
\hline Formal saline & $\begin{array}{l}100 \mathrm{ml} 40 \% \text { formaldehyde } \\
9 \mathrm{~g} \text { Sodium chloride } \\
900 \mathrm{ml} \text { Distilled water } \\
\text { Fixation time: } 12-24 \text { hours }\end{array}$ & $\begin{array}{l}\text { Formaldehyde mixture in isotonic saline has been widely used } \\
\text { for routine histopathology prior to administration of phosphate } \\
\text { buffered formalin. It usually produces formalin pigment. }\end{array}$ \\
\hline $\begin{array}{l}\text { Carnoy's } \\
\text { solution }\end{array}$ & $\begin{array}{l}60 \mathrm{ml} \text { Ethanol absolute } \\
30 \mathrm{ml} \text { Chloroform } \\
10 \mathrm{ml} \text { Glacial acetic acid } \\
\text { Fixation time: } 1-4 \text { hours }\end{array}$ & $\begin{array}{l}\text { Due to its rapid penetration properties it can be used for } \\
\text { detection of all tissues. Fine structure of nucleus is well } \\
\text { protected. It fixes glycogen and plasma cells well. In order not } \\
\text { to cause shrinkage or hardening, fixation which exceeds } 4 \\
\text { hours should be avoided. }\end{array}$ \\
\hline $\begin{array}{l}\text { Zinc formalin } \\
\text { (unbuffered) }\end{array}$ & $\begin{array}{l}1 \mathrm{~g} \text { Zinc sulphate } \\
900 \mathrm{ml} \text { Deionized water } \\
\text { (Stir until dissolved then } \\
\text { add) } \\
100 \mathrm{ml} 40 \% \text { formaldehyde } \\
\text { Fixation time: } 4-8 \text { hours }\end{array}$ & $\begin{array}{l}\text { Zinc formaldehyde solutions were developed as an alternative } \\
\text { to mercury chloride formulations. They are supported by the } \\
\text { work which states that they give better results with IHC. }\end{array}$ \\
\hline $\begin{array}{l}\text { Zenker's } \\
\text { fixative }\end{array}$ & $\begin{array}{l}950 \mathrm{ml} \text { Distilled water } \\
50 \mathrm{gr} \text { Mercuric chloride } \\
25 \mathrm{~g} \text { Potassium dichromate } \\
50 \mathrm{ml} \text { Glacial acetic acid } \\
\text { Fixation time: } 4-24 \text { hours }\end{array}$ & $\begin{array}{l}\text { The acetic acid-free stock solution can be preserved. Zenker is } \\
\text { an effective fixative for microanatomic structures and is used } \\
\text { because of its potent effect on cytoplasmic and fibril dyes. In } \\
\text { fresh material it is more efficient compared to post-mortem } \\
\text { tissues. However with this fixative red blood cells are not } \\
\text { protected sufficiently. Blocks are fixed for 3-8 hours and } \\
\text { washed with tap water to remove excess dross. Mercury } \\
\text { pigment is removed by the previous method. }\end{array}$ \\
\hline $\begin{array}{l}\text { Gendre's } \\
\text { solution }\end{array}$ & $\begin{array}{l}800 \mathrm{ml} \quad 95 \% \quad \text { Ethanol } \\
\text { saturated with picric acid } \\
150 \mathrm{ml} 40 \% \text { formaldehyde } \\
50 \mathrm{ml} \text { Glacial acetic acid } \\
\text { Fixation time: } 4 \text { - } 18 \text { hours }\end{array}$ & $\begin{array}{l}\text { Like the Bouin solution this fixative affects tissues positively. } \\
\text { In order to protect glycogen and other carbohydrates this is the } \\
\text { recommended fixative. After fixation, the tissue should be } \\
\text { placed in } 70 \% \text { ethanol. For the removal of yellow stains } \\
\text { washing should be administered. }\end{array}$ \\
\hline
\end{tabular}




\begin{tabular}{|c|c|c|}
\hline B-5 fixative & $\begin{array}{l}\text { Stock solution } \\
12 \mathrm{~g} \text { Mercuric chloride } \\
2.5 \mathrm{~g} \text { Sodium acetate } \\
\text { anhydrous } \\
200 \mathrm{ml} \text { Distilled water } \\
\text { Working solution, prepare } \\
\text { immediately before use B-5 } \\
\text { stock solution: } 20 \mathrm{ml} \\
2 \mathrm{ml} 40 \% \text { formaldehyde } \\
\text { Fixation time: } 4-8 \text { hours }\end{array}$ & $\begin{array}{l}\text { With this fixative morphological detail can be obtained at a high } \\
\text { level. It is used in the fixation of hematopoietic tissues. Nuclear } \\
\text { details are provided excellently. With this fixative IHC gives good } \\
\text { results. This, however, creates a rigid fixation that will cause the } \\
\text { tissue to disintegrate. Mercury pigment must be removed before } \\
\text { dyeing. The tissue should not be stored in B5 fixative, it should be } \\
\text { taken in } 70 \% \text { ethanol. }\end{array}$ \\
\hline Helly's fixative & $\begin{array}{l}1000 \mathrm{ml} \text { Distilled water } \\
25 \mathrm{~g} \text { Potassium dichromate } \\
10 \mathrm{~g} \text { Sodium sulphate } \\
50 \mathrm{~g} \text { Mercuric chloride } \\
50 \mathrm{ml} \mathrm{Immediately} \mathrm{before} \mathrm{use} \\
\text { add }-40 \% \text { formaldehyde } \\
\text { Fixation time: } 4-24 \text { hours }\end{array}$ & $\begin{array}{l}\text { It is added immediately before using } 5 \mathrm{cc} \text { formalin instead of } \\
\text { acetic acid in Zenker. Although Helly contains a liquid } \\
\text { oxidizing agent (potassium dichromate) and a reducing agent } \\
\text { (formalin), it is an excellent fixative. Helly is especially useful } \\
\text { for bone marrow, spleen, lymph glands, pituitary gland and } \\
\text { pancreas. Blocks should be fixed for } 6-24 \text { hours and the } \\
\text { mercury pigment should be removed as in Zenker. Helly can be } \\
\text { used both as a micro-anatomic and cytological (cytoplasmic) } \\
\text { fixative and as a second fixative after } 10 \% \text { formal-saline, such } \\
\text { as formal-sublimate. }\end{array}$ \\
\hline Methacarn & $\begin{array}{l}60 \mathrm{ml} \text { Methanol absolute } \\
30 \mathrm{ml} \text { Chloroform } \\
10 \mathrm{ml} \text { Glacial acetic acid } \\
\text { Fixation time: } 1-4 \text { hours }\end{array}$ & $\begin{array}{l}\text { Carnoy solution has similar properties. Less shrinkage and } \\
\text { hardening occurs. }\end{array}$ \\
\hline Bouin's solution & $\begin{array}{l}\text { Picric acid saturated aqueous } \\
\text { soln. }(2.1 \%): 750 \mathrm{ml} \\
250 \mathrm{ml} 40 \% \text { formaldehyde } \\
50 \mathrm{ml} \text { Acetic acid glacial } \\
\text { Fixation time: } 4-18 \text { hours }\end{array}$ & $\begin{array}{l}\text { It gives very good results with tricrom painted tissue. It protects } \\
\text { glycogen well but usually it lyses erythrocytes. Sometimes it is } \\
\text { recommended for gastrointestinal biopsies, animal embryos and } \\
\text { endocrine gland tissues. The stains due to picric acid are bright } \\
\text { yellowish color. Excessive picric must be washed from the tissues } \\
\text { before dyeing with } 70 \% \text { ethanol. Since the tissue may become } \\
\text { brittle, it shouldn't be fixed more than } 18 \text { hours. Because picric acid } \\
\text { may cause DNA degradation, intact DNA should not be used in } \\
\text { studies that require it. }\end{array}$ \\
\hline $\begin{array}{l}\text { Hollande's } \\
\text { solution }\end{array}$ & $\begin{array}{l}25 \mathrm{~g} \text { Copper acetate } \\
40 \mathrm{~g} \text { Picric acid } \\
100 \mathrm{ml} 40 \% \text { formaldehyde } \\
15 \mathrm{ml} \text { Acetic acid } \\
1000 \mathrm{ml} \text { Distilled water } \\
\text { Dissolve chemicals in distilled } \\
\text { water without heating. } \\
\text { Fixation time: } 4-18 \text { hours }\end{array}$ & $\begin{array}{l}\text { With this solution fixation of gastrointestinal canal specimens and of } \\
\text { endocrine tissues are advised. It produces less fragmentation than } \\
\text { Bouin. It has some decalcification properties. Since a solubilizing } \\
\text { phosphate precipitate will form, the fixative must be washed from } \\
\text { the tissues with a phosphate buffered formalin solution in the } \\
\text { processing machine. }\end{array}$ \\
\hline Clarke's solution & $\begin{array}{l}75 \mathrm{ml} \text { Ethanol (absolute) } \\
25 \mathrm{ml} \text { Glacial acetic acid } \\
\text { Fixation time: } 3-4 \text { hours }\end{array}$ & $\begin{array}{l}\text { This solution is used in frozen and smear samples. It can } \\
\text { produce fair results by conventional treatment in a very short } \\
\text { time, which provides better fixing time. Preserves the nucleic } \\
\text { acids but eliminates the lipids. Tissues can be directly } \\
\text { transferred to } 95 \% \text { ethanol. }\end{array}$ \\
\hline $\begin{array}{l}\text { Alcoholic } \\
\text { formalin }\end{array}$ & $\begin{array}{l}100 \mathrm{ml} 40 \% \text { Formaldehyde } \\
900 \mathrm{ml} 95 \% \text { Ethanol } \\
0.5 \mathrm{~g} \text { calcium acetate can be } \\
\text { added to ensure neutrality } \\
\text { Fixation time: } 12-24 \text { hours }\end{array}$ & $\begin{array}{l}\text { It combines the effect of formalin with the additional fixative } \\
\text { and cross-linking effects. Sometimes, the incomplete primer is } \\
\text { used during processing to secure the fixation after formalin } \\
\text { fixation. It can be used for fixation or correction of large fat } \\
\text { specimens (especially chest) because it allows lymph nodes to } \\
\text { be detected more easily when cleansing and removing lipids. } \\
\text { When used for primer fixation, tissue samples can be placed in } \\
95 \% \text { ethanol for direct processing. }\end{array}$ \\
\hline $\begin{array}{l}\text { Formol acetic } \\
\text { alcohol }\end{array}$ & $\begin{array}{l}85 \mathrm{ml} \mathrm{Ethanol} \mathrm{absolute} \\
10 \mathrm{ml} \mathrm{40 \%} \text { formaldehyde } \\
5 \mathrm{ml} \text { Acetic acid glacial } \\
\text { Fixation time: } 1-6 \text { hours }\end{array}$ & $\begin{array}{l}\text { It is also a substance that is faster than alcohol formalin due to } \\
\text { the presence of acetic acid, which can produce formalin } \\
\text { pigment. Sometimes used in Cryostat diagnostics to correct } \\
\text { insufficiently fixed regions. When used for primer fixation, the } \\
\text { samples can be placed directly into } 95 \% \text { ethanol. }\end{array}$ \\
\hline
\end{tabular}


structure of membrane systems in various cells. It is known that fixative changes the size of extracellular compartments of various adjuvants (13).

Concentration: The concentrations used in fixative for particular function is determined based on the effectiveness and solubility factors. In the experiments performed, it was determined that the effect of different concentrations of fixatives on the morphology obtained is different. Glutaraldehyde is normally used as a 3\% solution in the determination of electron microscope, but in the studies performed it has been found to be effective at $0.25 \%$ when the appropriate $\mathrm{pH}$ is provided. Aldehyde in the presence of buffers in the polymerization, has resulted in a reduction in effective concentration. Small concentrations of glutaraldehyde $(0.25 \%)$ have been found suitable (13).

Fixation time: For fixation the most commonly used agent is formalin. This is allowed to stand for 2-6 hours for sublimation in the fixation process. For electron microscopy, the chopped tissue is allowed to sit for 3 hours and then a buffer is recommended. In the case of formalin, the detection and washability of the tissues for 24 hours is checked. Formaldehyde and tissue component reacts quickly with each other. This long-term process of fixing with a fixative causes hardening of the tissue and causes shrinkage.

For electron microscopy, using glutaraldehyde as a fixing solution is more advantageous. Long-term fixations made with aldehydes would seriously affect enzyme activity. Limitations on this substrate and crosslinking between protein molecules cause diffusion (13).

Other factors affecting fixation: Volume change, substance addition, the use of detergent during fixation (13).

\section{References}

1. Grizzle WE. Special symposium: fixation and tissue processing models. Biotech Histochem 2009; 84: 185-193.

2. Junqueira LC, Carneiro J. Basic Histology text \& atlas, Nobel Medicine Bookstores, 2006; 1-2 (in Turkey).

3. Jamur MC, Oliver C. Cell fixatives for immunostaining. Methods Mol Biol 2010; 588: $55-61$.
4. Pekmez H, Camci NC, Zararsiz İ, et al. The effect of melatonin hormone on formaldehyde induced liver injury: A light microscopic and biochemical study. Firat Medical Journal 2008; 13: 92-97.

5. Yamashita S. Heat-induced antigen retrieval: Mechanisms and application to histochemistry. Progress in Histochemistry and Cytochemistry 2007; 41: 141-200.

6. van Essen HF, Verdaasdonk MA, Elshof SM, de Weger RA, van Diest PJ. Alcohol based tissue fixation as an alternative for formaldehyde: influence on immunohistochemistry. J Clin Pathol 2010; 63: 1090-1094.

7. Zararsız M, Kuş H, Yılmaz HR, Köse E, Sarsilmaz M. Antioxidant Effects Of Omega-3 Fatty Acids on Experimental Formaldehyde Toxicity induced İnjury of Hippocampus. FU Journal of Health Sciences 2008; 22: 59-64.

8. Ünsaldı E, Çiftci MK. Formaldehyde and its using areas, risk group, harmful effects and protective precautions against it. YYU Journal of Veterinary Medicine 2010; 21: 71-75.

9. Gugic D, Nassiri M, Nadji M, Morales A, Vincek V. Novel tissue preservative and tissue fixative for comparative pathology and animal research. Journal of Experimental Animal Science 2007; 43: 271-281.

10. Werner M, Chott A, Fabiano A, Battifora $H$. Effect of formalin tissue fixation and processing on immunohistochemistry. The American Journal of Surgical Pathology 2000; 24: 1016-1019.

11. Tingstedt JE, Tornehave D, Lind P, Nielsen J. Immunohistochemical detection of SWC3, CD2, CD3, CD4 and CD8 antigens in paraformaldehyde fixed and paraffin embedded porcine lymphoid tissue. Veterinary Immunology and Immunopathology 2003; 15: 94: 123-132.

12. Aktan TM, Cüce G, Tosun Z, Duman S. The effects of different fixatives on immunohistochemical staining of skin tissue. European Journal of Basic Medical Sciences 2012; 2: 46-49.

13. Bancroft JD, Stevens A, Turner DR. Theory and practice of histological techniques. Churchill Livingstone 1996; 1: 29-32 (in New York).

14. Hopwood D. The reactions of glutaraldehyde with nucleic acids. Histochemistry of Journal 1975; 7: 267-276.

15. Medawar PB. A second study of the behaviour and fate of skin homografts in rabbits: A Report to the War Wounds Committee of the Medical Research Council. J Anat 1945; 79: 157-176.

16. http://www.leicabiosystems.com/pathologyleade rs/fixation-and-fixatives-4-popular-fixativesolutions. 